Social perceptions of the impacts and benefits of invasive alien species: implications for management

Marina GARCÍA-LLORENTE*, Berta MARTÍN-LÓPEZ, José A. GONZÁLEZ, Paloma ALCORLO \& Carlos MONTES

\title{
Author's address:
}

Social-Ecological Systems Laboratory, Departament of Ecology, c. Darwin, 2, Edificio de Biología, Universidad Autónoma de Madrid, 28049 Madrid, Spain.

\section{Author's e-mail address:}

Marina García-Llorente: marina.garcia@uam.es

Berta Martín-López: berta.martin@uam.es

Paloma Alcorlo: paloma.alcorlo@uam.es

José A. González: jose.gonzalez@uam.es

Carlos Montes: carlos.montes@uam.es

${ }^{*}$ Corresponding author: C-201, Departament of Ecology, c. Darwin, 2, Edificio de Biología, Universidad Autónoma de Madrid, 28049 Madrid, Spain. Tel: +3491 4978008 Fax: +3491 4978001.marina.garcia@uam.es 
Social perceptions of the impacts and benefits of invasive alien species: implications for management

\begin{abstract}
Research on biological invasions has traditionally focused on the ecological component of invasive alien species, either without considering or by considering in a restringing way, the knowledge of the social component. Understanding the human dimension of invasions is critical to effectively tackling the problems associated with invasive species. We used questionnaires to evaluate the social perceptions and attitudes of different stakeholder groups affected by invasive alien species in the Doñana social-ecological system (SW Spain). Characteristics of respondents regarding their knowledge and attitudes toward biological invasions were categorized using hierarchical cluster and principal component analyses; while their potential support of eradication programs was assessed with a contingent valuation approach. Five stakeholder groups were recognized, differing in their degree of knowledge, perceptions, attitudes and willingness to pay for eradication. The fact that different stakeholders have remarkably different attitudes and perceptions about the impacts and benefits caused by alien invasive species should be considered in any decision-making process regarding their management, particularly for developing appropriate educational and informative programs. Public consultation with different stakeholders should also be encouraged from the beginning to avoid potential misunderstandings and to facilitate the implementation of management practices.
\end{abstract}

\title{
Keywords
}

Attitudes; Contingent valuation; Doñana social-ecological system; Eradication; Exotic species; Stakeholder analysis 


\section{Introduction}

Biological invasions are closely linked to historical and current human activities. However, a massive biotic homogenization of the Earth's surface is taking place as a result of the breakdown of the major biotic barriers that have historically kept the flora and fauna of the various continents quite separate (Crosby, 1988; Mooney et al., 2005). Currently, invasive alien species (IAS) are considered one of the most important causes of biodiversity loss and one of the major drivers of global change (Sala et al., 2000). The risk of introduction of IAS is being reinforced worldwide due to the development of new and fast transport systems that enhance increasing trade and tourist activities throughout the world (Perrings et al., 2005; Meyerson and Mooney, 2007). Once established, some exotic species have the ability to displace or replace native plant and animal species, disrupt nutrient and fire cycles, cause changes in ecosystems, lower biodiversity, and impact economic enterprises such as agriculture, forestry, fisheries, power production, and international trade (Lovell and Stone, 2005). In spite of this, some exotic species also have economic uses (Kendle and Rose, 2000). For instance, the world food supply is supported by nearly 20 species of plants, most of which are cultivated far from their place of origin (Mooney et al., 2005). In general, for every case of invasion some sector of society makes a profit (Baskin, 2002).

In this context, IAS must not only be characterized by their ecological impacts, but also by their social dimension (Zavaleta et al., 2001). Humans are involved in the entire process of invasion through functioning as vectors of introductions (accidental or intentional), suffering the consequences, and having the capacity to act and make decisions for managing them. In this sense, invasive species are a socioeconomic problem; one that requires solutions from economics and sociology (Perrings et al., 2000, 2002). On one hand, the economic dimension of invasions began to be studied a decade ago (Perrings et al., 2000; Pimentel, 2002), but most research has focused on the quantification of direct economic costs of IAS, ex-post assessments and have methodological shortcomings compared to their theoretical basis (Born et al., 2005). Although the economics of IAS are still not well understood or documented, estimations indicate that the costs are quite high, in the range of millions to billions of dollars per year (Pimentel et al., 2005). This situation is creating a paradox for policymakers who aim to simultaneously encourage trade while minimizing the costs of invasive species (Lovell and 
Stone, 2005; Keller and Lodge, 2007). On the other hand, relatively little attention has been focused on public attitudes toward IAS, probably because of the difficulty in measuring the social impacts it causes, and because of the conflicts between different stakeholders. However, in recent years, there has been an increasing effort to study public attitudes toward concrete eradication and control options (Fraser, 2006; Bremner and Park, 2007; Fischer and van der Wal, 2007), different ways to perform IAS risk analysis (Simberloff, 2003; Keller and Lodge, 2007), and control management plans (Simberloff, 2005; Hulme, 2006). Other studies have emphasized the necessity of involving different sectors of modern society in the management of IAS (McNeely, 2001). Despite this, there are still many gaps to be resolved in our knowledge of prevention, control, eradication, and management of IAS. In this sense, a better understanding of human knowledge, perception and attitudes toward IAS arises as an urgent problem that needs to be addressed as soon as possible.

In the face of global change, a better integration of research findings regarding biological invasions from the ecological and socioeconomic disciplines is needed for an improved understanding of the complexity of the problems associated with IAS. The economics of IAS help policy makers in designing management practices and could engage the public though the information available about financial cost (Meyerson and Mooney, 2007). However, public attitudes toward IAS could engage the public through their participation and could help the decision-making process.

The aim of our study is to assess the perception of different stakeholders affected by IAS and to evaluate the implications for public support of management practices. In particular, we focused on the differences between stakeholder perceptions about the impacts and benefits generated by IAS and their management. To achieve these goals we: (1) identified and characterized the different stakeholders positively or negatively involved with IAS, (2) evaluated their knowledge and perception of the problems associated with IAS, and (3) analyzed their attitudes toward IAS management, including their willingness to pay (WTP) for IAS eradication. This paper contributes in a significant way by taking an interdisciplinary approach to tackling the problem of IAS while considering economic, social and ecological dimensions to find the trade-offs involved 
in the management of IAS. As far as we know, this is the first study that characterizes stakeholders based on social perceptions toward IAS.

\section{Materials and methods}

\subsection{Study area}

The study was performed in Doñana, one of the most emblematic wetlands in the Mediterranean Basin, which is located on the southwestern coast of Spain. In this paper, we consider Doñana as a social-ecological system (SES) (in the sense of Folke et al., 2003). Its ecological limits are referred to as the Greater Fluvial-Littoral Ecosystem of Doñana (2 207 $\mathrm{km}^{2}$ ), which is composed of four different ecodistricts: marshes, aeolian sheets, coastal systems and an estuary (Montes et al., 1998) (Fig. 1).

Currently, Doñana is characterized by its conservation policies and management measures but also by its tourism, urbanization projects, and the expansion of agriculture. In this sense, although more than the $40 \%$ of Doñana is protected by the Natural Protected Area (NPA) -i.e., National and Natural Parks- and its population is no greater than 174000 inhabitants, Doñana is suffering from important impacts of IAS, and therefore management is essential for the conservation of this valuable natural area (García-Novo and Marin, 2005).

\subsection{Sampling strategy and questionnaire design}

We obtained 472 questionnaires with three different sampling methods: (1) 366 direct face-toface interviews developed at 19 sample points in the Doñana SES such as visitor centers of the NPA, urban zones, recreational areas, beaches, and agricultural fields (Fig. 1), (2) 55 indirect interviews conducted with managers in the Department of Environment of the Andalusian Government in Seville, where the questioner was present but we did not formulate the questions, and finally (3) 51 no-presence questionnaires that were sent out by mail to different researchers in Spain who knew about the problem of IAS in Doñana. This sampling methodology had certain limitations because the information would have been more homogeneous if we had conducted all the questionnaires using one unique method, but because of the difficulty of conducting direct face-to-face interviews with researchers in different locations throughout Spain, we developed their questionnaires by email. 
The questionnaire was given to people older than 18 years of age between June 2006 -

September 2007. Validation of the final data collection was checked against previous studies that focused on visitors (Gómez-Limón et al., 2003), and users of the Doñana SES (MartínLópez et al., 2007).

Questionnaires consisted of five sections of questions about: (1) user activities in the Doñana SES, (2) knowledge and perception of the impacts of IAS, (3) user attitudes toward the introduction of IAS and management, including a question about their WTP for eradicating these species, (4) their general environmental behavior, and (5) socio-demographic information (see Appendix A).

The sample population was randomly selected because we were trying to question different users who may be affected by the introduction of IAS either positively or negatively. The sample population consisted of: users of services provided by the four ecodistricts (marshes, aeolian sheets, coastal systems and the estuary), tourists (beach, religious, nature and birdwatchers) and conservationists (managers and researchers).

\subsection{Selection of target species}

In total, respondents valuated the impact of 15 IAS (Table 1) of the nearly 200 exotic species recorded in the Doñana SES. To select the species, we considered ecological, social and management factors.

The ecological factors were represented by: (1) IAS competition with native species, (2) predation toward native species, (3) hybridization between IAS and native species, (4) impact on ecosystems structure and function caused by IAS, and (5) particular endangered species threatened by IAS, according to the National and Autonomic Catalogues of Threatened Species (Royal Decree 439/1990 and Law 8/2003, respectively) and the Red Lists of species at different scales: (1) International (Smith and Darwall, 2006), (2) National (Pleguezuelos et al., 2002; Bañares et al., 2004; Madroño et al., 2004) and (3) Autonomic (Blanca et al., 2002). The social factors were related to socioeconomic uses of the species and their role in disease transmission. 
Finally, we included management factors at a global scale, for example if the species had been recognized as threatening according to the " 100 of the world's worst invasive alien species" list (Lowe et al., 2004), and at the local scale, i.e., if the Department of Environment of the Andalusian Government or the Doñana National Park had developed eradication, control, research or educational programs for IAS.

\subsection{Data analysis}

\subsubsection{Identification and characterization of stakeholders}

First, to classify stakeholder relationships with IAS, we used a hierarchical cluster analysis, using the Euclidean distance and Ward's method. Second, to characterize stakeholders, we used principal component analysis (PCA). For both characterizations, the explanatory variables were related to stakeholder knowledge, perception and attitudes toward the impacts of IAS, general environmental behavior, and socioeconomic variables. The variables used to identify and characterize stakeholders are presented in Table 2.

To analyze the differences among stakeholders regarding their knowledge and their attitudes toward the introduction of IAS, we carried out an analysis of variance (ANOVA).

\subsubsection{Willingness to pay for IAS eradication}

The contingent valuation $(\mathrm{CV})$ method uses questions to elicit respondent preferences by finding the maximum amount that the respondent would be willing to pay for improvements in the quality and/or quantity contingent upon the creation of a hypothetical market (Mitchell and Carson, 1989). In this study, we used CV to identify stakeholder WTP for eradicating the selected IAS (Table 1). At this stage of the questionnaire, we showed a picture of the IAS to give more information to the respondents.

We used an open-ended elicitation format (see Appendix A). Many researchers prefer the closed-ended format because open-ended questions are more difficult to answer and the question format is not incentive compatible (Carson et al., 2000). However, by using openended questions we obtained a more realistic and direct measure of the maximum WTP without anchoring bias. 
A common problem in the analysis of open-ended CV-bids (Mitchell and Carson, 1989) is that there are a large number of responses with zero WTP. One way to deal with this is to use a Heckman model (Heckit), wherein 'pay or not' is estimated first and the positive WTP is then estimated (Greene, 2000; Sigelman and Zeng, 1999).

Following Sigelman and Zeng (1999), the Heckit model is a response to sample selection bias, which arises when data are available only for cases in which a variable reflecting 'pay', $z^{*}$, exceeds zero.

$$
\begin{aligned}
& z_{i}^{*}=w_{i} \gamma+\mu_{i} \\
& y_{i}^{*}=X_{i} \beta+\mu_{i} \text { observed only if } z_{i}^{*}>0
\end{aligned}
$$

where for the ith individual, $X_{i}$ is a vector of explanatory variables, $\beta$ is a parameter vector common to all individuals, and $\mu_{i}$ is a random disturbance term. The error terms are assumed to follow a bivariate normal distribution with means 0 , variances $\sigma_{\mu}=1$ and $\sigma_{\varepsilon}$ and correlation coefficient $\rho$. The observed variable is $z=0$ if $z^{*} \leq 0$ and $z=1$ if $z^{*}>0 ; y=0$ if $z^{*} \leq 0$ and $y=y^{*}$ if $z^{*}>0$. The expected $Y$ is:

$$
E\left(y \mid z^{*}>0\right)=X \beta+\rho \sigma_{\varepsilon} \lambda(-w \gamma)
$$

where $\lambda(-w \gamma)=\frac{\phi(-w \gamma)}{1-\Phi(-w \gamma)}$ is the inverse of the Mill's ratio, $\phi$ is the standard normal density function, and $\Phi$ the standard normal function.

Equation (3) implies that the conditional expectation of $y$ is $X \beta$ only when the errors of Eqs (1)

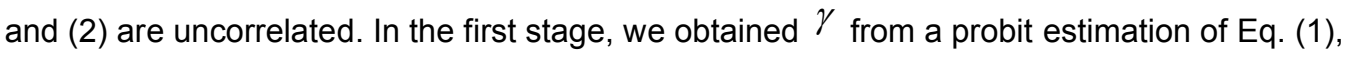
where $z=1$ if $z^{*}>0$ and 0 otherwise. Pseudo $R^{2}$ was calculated according to Veall and Zimmermann (1992). In the second stage, we estimated Eq. (3) using ordinary least squares (OLS) regression.

The variables used in both stages of the Heckit model are presented in Table 2. 
Results obtained by the Heckit model were analyzed by ANOVA and Canonical Correspondence Analysis (CCA) to determine the non-economic factors that influence WTP and how they were related to stakeholder typology.

\section{Results}

\subsection{Classification of stakeholders}

Five groups of stakeholders were categorized in the cluster analysis with a coefficient of dissimilarity of 0.67 (Fig. 2): (1) local users (20\%), generalist tourists (18\%), nature tourists (35\%), conservation professionals-group 1 (13\%), and conservation professionals-group 2 (14\%). At the highest coefficient of dissimilarity two different clusters were found: the first represented both groups of conservation professionals, and the second included the users of ecosystem services (i.e., both groups of tourists and local users).

Stakeholder category variance (54.1\%) was explained by three factors in the PCA (Table 4). Factor $1(27.23 \%)$ captured stakeholder general environmental behavior and general knowledge about IAS. While positive loadings reflected general environmental attitudes, knowledge about IAS and education level, being associated with conservation professionals and nature tourists; negative loadings reflected an absence of awareness toward the willingness to introduce exotic species, and were associated with local users and general tourists. Factor 2 (15.54\%) captured the perception about the role of IAS, in which positive loadings reflected the impact of IAS on the social system, and negative loadings reflected the IAS impact on ecosystems. In this sense, we found two different views among stakeholder groups. While generalist tourists, nature tourists and conservation professionals-group 2 perceived that IAS had an ecological role through the threats they posed to ecosystems, local users and conservation professionals-group 1 considered that IAS are not only an ecological problem, but also have an important social component related to factors such as the economy, cultural identity and human health. In this manner, local users had a utilitarian or anthropocentric relationship with IAS. They considered that IAS had an economic benefit or, on the contrary, that these species could cause sanitary problems. Finally, conservation professionals-group 1 perceived that IAS caused social impacts (Table 3). Factor 3 (11.30\%) captured the sense of 
place of the stakeholders. The variables that contributed most to this factor were the distance between the place of residence and Doñana, and the effect of IAS on cultural identity; both of these had positive loadings. Local users and both groups of conservation professionals were associated with positive loadings, and the two groups of tourists with negative loadings.

The local users group was comprised of people whose site of origin was nearest the study area, education level was poor and environmental attitudes were poor (Table 3 ). In this group we could identify two subgroups of local people (Fig. 2). The first was formed by people with a strong relationship with provisioning services of Doñana ( $12 \%$ of local users) such as fishermen, beekeepers, crayfish fishermen, seafood collectors, rice farmers, and farmers in general. A second group formed by local people had a weak relationship with provisioning services $(8 \%$ of local users); these were people associated with the building industry, shop assistants or housewives. In spite of this, the two subgroups were analyzed together in the local users group because their perception of IAS was similar. The motivation of general tourists was not directly related to the NPAs, because they preferred to go to the beach or to religious events. Consequently, this group was composed basically of beach tourists and pilgrims. Also some tourists were one-day visitors (Martín-López et al., 2007), whose motivation was to spend one day in the Doñana NPA. Nature tourists showed interest for visiting only the NPA to enjoy the natural landscapes and wildlife, usually linked with activities like bird-watching or nature guide routes. Finally, the two groups of conservation professionals were composed of managers and researchers, whose education level was the highest. The difference between these groups was their perception of the role of IAS and their environmental behavior. Whereas group 1 perceived that IAS caused social impacts and only $30 \%$ of them were members of an environmental NGO, group 2 perceived that IAS had an ecological role and $100 \%$ of them were a member of a NGO (Table 3).

\subsection{Stakeholder knowledge and perception of the impact of IAS}

Of all respondents, $75 \%$ knew the meaning of IAS, but a detailed comparison demonstrated the existence of significant differences among stakeholders (ANOVA, $F=70.64, p<0.001$ ). The group with the lowest knowledge was the generalist tourists followed by the local users. The other three stakeholder groups had higher levels of knowledge (Table 3). 
When stakeholders were asked to name which exotic species they knew to exist in Doñana, local users only recognized those species that brought economic benefits to them, such as Procambarus clarkii to the crayfish fishermen. In the same way, P. clarkii was the most mentioned species by generalist tourists. The other three stakeholder groups had a high level of knowledge about the exotic species in Doñana (Table 3). In general, at least 30 species were recognized as having been introduced. The taxonomic group that was mentioned more was vegetation (44\% of respondents recognized a plant as an exotic species), followed by vertebrates $(32 \%)$, and invertebrates $(24 \%)$. Specifically, the most commonly mentioned species were: P. clarkii (29\%), Carpobrotus edulis (17\%), Trachemys scripta (17\%), Eucalyptus spp. (14\%), and Azolla filiculoides (9\%). Many of the respondents only recognized those species that have informative panels or exhibits in the NPA (i.e., C. edulis and T. scripta).

When we evaluated the respondents' historic memory, the most recognized exotic species were P. clarkii, which was introduced in 1974 (Habsburgo-Lorena, 1986), and Eucalyptus spp. which was first cited by Rivas-Martínez et al. (1980). These two species were recognized as exotic species by $90.5 \%$ and $65.7 \%$ of respondents, respectively. In contrast, species introduced in the past such as Dama dama, which was introduced at the beginning of the $20^{\text {th }}$ century (Blanco, 1998), Cyprinus carpio, which was introduced in the $17^{\text {th }}$ century during de Habsburgo's dynasty (Lozano-Rey, 1935), and Genetta genetta, which was an Arabian introduction in the $8^{\text {th }}$ $-14^{\text {th }}$ centuries (García-Novo and Marin, 2005), were only recognized by a small proportion of the respondents $(32.6 \%, 41.5 \%$, and $22.0 \%$, respectively). Thus, there was a relationship between the number of people that knew about the introduction of a species and the time period of its introduction (Fig. 3).

Finally, the species perceived to be the most threatening IAS by respondents were: $P$. clarkii (72\% of respondents perceived this as the most threatening species), Eucalyptus spp. (49\%), $T$. scripta (46\%), C. edulis (37\%), A. filiculoides (36\%), C. carpio (27\%), Oxyura jamaicensis (20\%), Eriocheir sinensis (18\%), Linepithema humile (17\%), and Pelodiscus sinensis (15\%).

\subsection{Stakeholder attitudes toward the introduction of IAS and management}


There was a small percentage of respondents (18\%) willing to introduce exotic species if they could obtain an economic or recreational benefit for themselves, but we found differences among stakeholder groups (ANOVA, $\mathrm{F}=65.22, \mathrm{p}<0.001$ ). While the awareness of generalist tourists about the impacts of introduced species was very low $(60 \%$ of them were willing to introduce an exotic species), and nearly $30 \%$ of local users considered that the introduction of exotic species would be positive if they profited from this action, the other three groups were not willing to do it.

A total of 454 respondents $(97 \%)$ agreed that eradication of some IAS that have negative impacts is necessary. All stakeholders agreed that the impact of IAS on ecosystems is an important motive for their eradication. Some respondents had different motivations. For example, while local users and conservation professionals-group 1 considered the importance of the impacts on the local economy, generalist tourists thought about the existence value of the species threatened by IAS (i.e., the right that endangered species have to exist) (Table 3).

\subsubsection{Willingness to pay for IAS eradication}

A total of 280 respondents (59.3\%) refused to participate in the CV procedure. Zero values were recorded for 93 of them (19.7\%) and 187 respondents (39.6\%) gave protest responses because of different motives. Some respondents who gave protest zeros $(16.3 \%)$ felt that the responsibility for solving the problem lay with the Environmental Government; others did not agree with the payment of new taxes for funding eradication programs (11.4\%). Some were worried about Government policies (3\%), others did not live in the Doñana SES or near it $(2.3 \%)$, and some preferred to help the process with their work and advice, but not in paying for it $(2.1 \%)$. A total of 21 respondents $(4.5 \%)$ had other specific motives for not paying for IAS eradication.

We found 7 significant variables which explained the probability of participation in the hypothetical market in the Probit regression (Table 5). The variables ECONOMY, DISEASE, EDUCATION, AGE and HOUSESIZE were statistically negative, and DISTANCE and ATTITUDE were positive. If the respondent was receptive to the questionnaire, the probability of 
participation in the hypothetical market was higher; this also happened with more DISTANCE. As we expected, the AGE variable showed that younger people were more aware of IAS concerns than older people, and a smaller HOUSESIZE also had a higher probability of participating in the hypothetical market. On the other hand, people that recognized the economic role of IAS and respondents with high education levels were less willing to participate in the hypothetical market.

On the second stage of the Heckit model (Table 6), we found 4 statistically positive variables: DISTANCE, INCOME, ATTITUDE, and UNDERSTANDING; and 3 negative ones: ECONOMY, EDUCATION, and HOUSESIZE. As we expected, a better UNDERSTANDING and ATTITUDE toward the questionnaire influenced the respondents to say that they would pay higher amounts of money. Also, WTP strongly depends on higher INCOME and greater DISTANCE. In this sense, people who had traveled further to visit Doñana were more likely to contribute higher WTP than local people.

Conversely, people who recognized the economic role of IAS contributed to the IAS eradication with lower amounts of money, because they related IAS with direct economic benefits (e.g., crayfish fishermen that profited from P. clarkii, or beekeepers whose beehives depend mostly on Eucalyptus spp.). Similarly, people who had high EDUCATION were associated with lower WTP because these people usually suggest other kinds of solutions (e.g., they prefer to help with their work and advice, but not with money). Finally, as we expected, a larger HOUSESIZE was negatively related to WTP.

The attitudes towards WTP for IAS eradication showed that stakeholders were more willing to pay for species that produce acute impacts on ecosystems (i.e., C. carpio, freshwater plants such as $A$. filiculoides and P. stratiotes, and Eucalyptus spp.) than for those that had more diffuse effects on ecosystems, but were easily identifiable with impacts over emblematic or particular endemic species (i.e., O. jamaicensis, T. scripta, or other fishes such as Fundulus heteroclitus, Lepomis gibbosus, and Micropterus salmoides) (Table 7). Furthermore, WTP for $L$. humile eradication may be related to a kind of phobia toward insects. 
Differences among stakeholder WTP for eradication of particular species were found (Table 7), especially for those species that received the lowest amount of money for being eradicated (e.g., fishes, T. scripta, C. edulis, and Gambusia holbrooki). In this sense, stakeholders with a higher awareness for eradicating these species were both conservation professionals groups and nature tourists.

Different relationships between stakeholders and their WTP for eradication of particular species were also found in the CCA (Table 8, Fig. 4). Factor 1 captured those IAS that had eradication or research programs. The two groups of conservation professionals were positively associated with factor 1 , while local users and tourists were negatively associated. On the one hand, species such as $T$. scripta, C. edulis, and Eucalyptus spp. have been the targets of important eradication programs in Doñana and O. jamaicensis have been the object of eradication programs at a national scale. On the other hand, species such as $P$. clarkii, $A$. filiculoides, and L. humile have been objects of research programs. Factor 2 captured the popularity-threat perception attributes. Nature tourists and conservation professionals-group 1 were positively related, whereas generalist tourists, local users, and conservation professionals-group 2 were negatively related. On one hand, nature tourists were related with popular species that had easily identifiable impacts on the structure and functioning of the ecosystem, e.g., freshwater plants, Eucalyptus spp. and P. clarkii. Similarly, the conservation professionals-group 1 was willing to pay for eradicating species with a particular social role. These species were Eucalyptus spp., which had a strong eradication campaign, $T$. scripta, which had an awareness campaign, and other fishes, which were strong related with human uses (recreational or ornamental). On the other hand, generalist tourists, local users, and conservationist professionals-group 2 were WTP for those IAS that affected them specifically. For example, while local users preferred to eradicate $L$. humile because it affects different crops (Carpintero et al., 2001), conservationist professionals-group 2 preferred to eradicate O. jamaicensis or $C$. edulis because they had large ecological impacts.

\section{Discussion}


Social perception about IAS has been studied under different approaches: (1) randomly taking into account the general public (Jetter and Paine, 2004), (2) including only those stakeholders involved in IAS management (Bardsley and Edward-Jones, 2006), or (3) characterizing stakeholders by reviewing institutional context (Binimelis et al., 2007). In this study, we tried to collect a sample of all stakeholders, positively or negatively involved with IAS, some of them having influence on IAS management and some with no influence. Our analysis revealed the existence of different stakeholders related to: (1) knowledge of IAS meaning, (2) knowledge about the number of introduced species (3) perception of the role of IAS in the ecosystem and the social system, (4) motivation for eradication, (5) willingness to introduce exotic species, and (6) WTP for IAS eradication.

We found two different conservation professional groups due to their different perceptions of the role of IAS. In spite of this, they were usually considered to be one group (Kennedy, 1985). Conservation professionals-group 1 were more willing to consider the different ecological and social factors involved in the process of invasion and though that it was necessary to incorporate human practices, attitudes and perceptions in the management of IAS. On the other hand, conservation professionals-group 2 thought that the ecological impact caused by IAS was a strong enough reason by itself for IAS management. This group specifically considered the intrinsic value of biodiversity as the main reason for managing biological invasions.

Regarding the conception of the term alien invasive species, we found a relationship between the number of respondents who recognized a species as being introduced and the historical date of introduction. In a study of stakeholder perceptions of the impacts of IAS conducted in the Mediterranean islands (Bardsley and Edward-Jones, 2006), many respondents were surprised that naturalized exotic species were not native. Furthermore, they considered the introduction and naturalization of exotic species to be part of an ongoing process of environmental change. Another study by Fischer and van der Wal (2007) showed that Lavatera arborea, which has invaded one of the largest UK colonies along the east coast of Scotland, was not perceived as a "new" species by $75 \%$ of respondents. In our study, species introduced in the past, such as $C$. carpio, $D$. dama and $G$. genetta were only recognized as being exotic by a low percentage of respondents, while recent introductions such as $P$. clarkii or Eucalyptus 
spp. were mostly recognized by respondents as invasive. These results suggest that the meaning of IAS is a social dynamical concept, in which the more recent the species introduction the more recognizable is the species as being exotic by respondents.

With regard to the term of IAS and its knowledge, we found that the most renowned introduced species in our study were: P. clarkii, C. edulis, T. scripta, Eucalyptus spp. and A. filiculoides. Carpobrotus spp. and Eucalyptus spp. were also identified in a ranking of most commonly mentioned invasive exotic plants in the Mediterranean islands (Bardsley and Edward-Jones, 2007). Furthermore, two of the five most commonly mentioned species in our study (C. edulis and T. scripta) have been the objective of informative campaigns in the Doñana NPA, suggesting that society is sensitive to educational and informative programs. Such campaigns have also been undertaken in other Mediterranean regions with success (Bardsley and EdwardJones, 2007). Consequently, our findings have important implications in environmental policies regarding IAS management, because the knowledge acquired in educational and informative programs could influence individual attitudes and behaviors toward IAS.

Developing public awareness campaigns to support IAS management, including sharing information about IAS impacts, is a useful and interesting tool for engaging the general public. In this sense, several studies have demonstrated the importance of stakeholder engagement in IAS management (Stokes et al., 2006) and the necessity of counting on their support as the key to success or failure of the projects undertaken by conservation managers (Bremner and Park, 2007). The opposition from a part of society could cause the failure of an eradication project (Genovesi and Bertolino, 2001). We found that the majority of respondents $(97 \%)$ agreed that eradication of some potentially negative IAS could be necessary. Other studies have obtained similar results (Philip and Macmillan, 2005; Bardsley and Edward-Jones, 2006; Bremner and Park, 2007). These high levels of support show that public participation is possible.

An interesting tool for evaluating social support with regard to IAS eradication is the CV method. We found that higher WTP amounts for eradicating species would be given to those IAS that produce general impacts on ecosystems (i.e., C. carpio, A. filiculoides, P. stratiotes, and Eucalyptus spp.) and to those species that traditionally cause biophobia (e.g., L. humile). 
Consequently, future research should focus on analyzing the relationships between stakeholder perceptions and WTP for eradicating species, as well as the relationship between IAS and the supply of ecosystem services, and how the impact of IAS on ecosystem services is perceived by stakeholder groups.

\section{Conclusions}

Accounting for the importance of social perceptions and stakeholder attitudes in relation to exotic species, some considerations emerge from our study that could be relevant for IAS management. Our results are consistent with the widely accepted idea that the human dimension is critical for successful IAS management. Policies that did not have public support in the past have usually failed (Mack et al., 2000; Genovesi and Bertolino, 2001).

It should be noted that most stakeholders and decision makers have only a limited perception of the problem and, therefore, education and public awareness campaigns are extremely important for any successful management of the problems associated with IAS (UE, 2003). Awareness campaigns are critical activities, not only for preventing new invasions but also for changing public perceptions and for ensuring public support on eradication and control programs (Tavares, 1997; Wittenberg and Cock, 2001).

However, the fact that different stakeholders have remarkably different attitudes and perceptions about the impacts and benefits generated by IAS deserves special attention and should be taken into account in any decision-making process. In this sense, appropriate educational and informative programs should be designed for specific groups of stakeholders if they are to be effective. These programs should take into account stakeholder interests, educational levels, environmental behaviors and personal experiences.

Public consultation with different local user groups and institutional stakeholders at different spatial scales should also be encouraged from the beginning of any program to avoid potential misunderstandings and to facilitate the implementation of management practices.

\section{Acknowledgements}

The authors gratefully acknowledge Doñana National and Natural Park for providing facilities to obtain data, and to those tourists, local users and researchers who took their time to respond to 
the questionnaire. Funding for this project was provided by the Spanish Ministry of Environment (Project CGL2006-14121) and the Department of Environment of the Andalusian Government (Project NET413308/1).

\section{Appendix A. Structure and content of the questionnaire}

\subsection{User activities in the Doñana SES}

Information about the motivation of the activities in the Doñana SES of the respondent, such as: research, management, resting, going to the beach, religious travel, etc.

\subsection{Knowledge and perception of the impact of IAS in Doñana SES}

a. Definition of the term alien invasive species.

b. Knowledge of any exotic species in Doñana SES.

c. Knowledge about the introduction of five exotic species into Doñana SES with the objective of evaluating historic memory. Specifically we asked about eucalyptus (Eucalyptus spp.), red swamp crayfish (P. clarkii), common carp (C. carpio), fallow deer (D. dama) and genet (G. genetta)

d. Perception of the more threatening species. For this question, we showed 15 exotic species in Doñana SES with different levels of impacts and asked respondents to select the six most dangerous specimens; each IAS was illustrated with a picture. These species were: A. filiculoides, C. edulis, Eucalyptus spp., Pinus pinea, L. humile, E. sinensis, P. clarkii, P. sinensis, T. scripta, C. carpio, L. gibbosus, M. salmoides, Oncorhynchus mykiiss, O. jamaicensis and D. dama; respondents could also suggest other species not listed, or ones that they thought were an important threat.

e. Perception of the role of IAS in Doñana SES.

\subsection{Attitudes toward the introduction of IAS and IAS management}

a. Willingness to introduce exotic species if they could obtain an economic or recreational benefit for themselves.

b. If they consider eradication to be a good management option and why it may be necessary. 
c. WTP for IAS eradication: To determine people's awareness and level of participation toward the impact of IAS in the Doñana SES, we asked them about their WTP for eradicating IAS that we selected. The purpose of this question was to explore stakeholder attitudes toward paying for IAS eradication, and to know which species were most important to which stakeholders. For this question, each IAS was illustrated with a picture and a description explaining the ecological and socioeconomic impacts that they had on biodiversity and ecosystem services of the Doñana SES. In this context, within the CV framework, we suggested the following question:

'With the knowledge that you have about the impacts generated by the presence of (species name), would you be willing to pay an annual contribution to a fund created by the Environmental Government to eradicate this species in Doñana SES?'

If respondents answered 'No,' then they were asked the reason for not contributing to the fund to differentiate protest answers from zero values. If respondents answered 'Yes,' we asked them how much money $(€)$ they would contribute. The elicitation of WTP was an open-ended format question.

\subsection{General environmental behavior}

This was measured by traditional variables that are considered to be indicators of respondent interest in nature (Requena, 1998):

a. If the respondent held a membership in an environmental organization.

b. Number of other natural protected areas that the respondent had visited during the previous year.

\subsection{Socio-demographic information}

Social and demographic information included variables of age, gender, education level, employment, household size, monthly family income and place of residence to estimate how far respondents had traveled. 


\section{References}

Bañares, A., Blanca, G., Güemes, J., Moreno, J. C., Ortiz, S., 2004. Atlas y Libro Rojo de la Flora Vascular Amenazada de España. Dirección General de Conservación de la Naturaleza, Ministerio de Medio Ambiente, Madrid, España.

Bardsley, D., Edward-Jones, G., 2006. Stakeholders' perceptions of the impacts of invasive exotic plant species in the Mediterranean region. GeoJournal 65, 199-210.

Bardsley, D., Edward-Jones, G., 2007. Invasive species policy and climate change: social perceptions of environmental change in the Mediterranean. Environmental Science and Policy $10,230-242$.

Baskin, Y., 2002. A plague of rats and rubbervines: the growing treat of species invasions. Island Press, Washington D.C., USA.

Binimelis, R., Monterroso, I., Rodríguez-Labajos, B., 2007. A social analysis of the bioinvasions of Dreissena polimorpha in Spain and Hydrilla verticillata in Guatemala. Environmental Management 40, 555-566.

Blanca, G., Cabezudo, B., Hernández-Bermejo, J. E., Herrera, C. M., Muñoz, J., Valdés, B., 2000. Libro Rojo de la Flora Amenazada de Andalucía (Tomo I y II). Consejería de Medio Ambiente, Junta de Andalucía, Andalucía, España.

Blanco, J.C., 1998. Mamíferos de España. Planeta, Barcelona, España.

Born, W., Rauschmayer, F., Bräuer, I., 2005. Economic evaluation of biological invasions-a survey. Ecological Economics 55, 321-336.

Bremner, A., Park, K., 2007. Public attitudes to the management of invasive non-native species in Scotland. Biological Conservation 139, 306-314.

Carpintero, S., Retana, J., Cerda, X., Reyes-López, J., De Reyna, L.A., 2007. Exploitative strategies of the invasive Argentine ant (Linepithema humile) and native ant species in a southern Spanish pine forest. Environmental Entomology 36, 1100-1111. 
Carpintero, S., Tinaut, A., Reyes, J., Arias de Reyna, L., 2001. Estudio faunístico de los formícidos (Hymenoptera, Formicidae) del Parque Nacional de Doñana. Boletín de la Asociación Española de Entomología 25, 133-152.

Carson, R., Groves, T., Machina, M., 2000. Incentive and information properties of preference questions. Working Paper, Department of Economics, University of California, California, USA.

Consejería de Agricultura y Pesca (CPA)-Junta de Andalucía., 2001. Estudio sobre el impacto económico del sector de cangrejo de río en Andalucía, Andalucía, España.

Consejería de Medio Ambiente (CMA)-Junta de Andalucía., 2003. Medio ambiente invierte un millón de euros en un plan de recuperación del enebro costero. Boletín 4.1.

Crosby, A., 1988. Imperialismo ecológico. La expansión biológica de Europa, 900-1900. Crítica, Barcelona, España.

Dana, E.D., Sanz, M., Vivas, S., Sobrino, E., 2005. Especies vegetales invasoras en Andalucía. Dirección General de la Red de Espacios Naturales Protegidos y Servicios Ambientales, Consejería de Medio Ambiente, Junta de Andalucía, España.

de Macalel, M., Vlek, P., 2004. The role of Azolla cover in improving the nitrogen use efficiency of lowland rice. Plant and Soil 263, 311-321.

Doadrio , I., 2001. Atlas y libro rojo de los peces continentales de España. Ministerio de Medio Ambiente, Madrid, España.

European Commission., 2003. Thematic report on alien invasive species, second report of the European Community to the Conference of the Parties of the Convention on Biological Diversity.

Fernández-Zamudio, R., Cirujano, S., Nieto Gil, I., Cobo, M.D., Sousa Martín, A., García Murillo, P., 2006. Novedades florísticas en el Parque Nacional de Doñana (SW España). Acta Botanica Malacitana 31, 191-195.

Fernández-Delgado, C., Drake, P., Arias, A.M., García, D., 2000. Peces de Doñana y su 
entorno. Organismo Autónomo Parques Nacionales, Secretaría General de Medio Ambiente, Ministerio de Medio Ambiente, Madrid, España.

Figueroa-Clemente, M.E., 2003. Diversidad genética y diversidad ecológica. Revista Medio Ambiente, Consejería de Medio Ambiente, Junta de Andalucía 42.

Fisher, A., van der Wal, R., 2007. Invasive plant suppresses charismatic seabird - the construction of attitudes towards biodiversity management options. Biological Conservation 135, 256-267.

Folke, C., Colding, J., Berkes, F., 2003. Synthesis: Building resilience and adaptive capacity in social-ecological systems, in: Berkes, F., Colding, J., Folke, C. (Eds.), Navigating socialecological Systems: building resilience for complexity and change. Cambridge University Press, Cambridge, UK, pp. 352-387.

Fraser, A., 2006. Public attitudes to pest control. A literature review. Science and Technical Publishing, Wellington, New Zealand.

García-Berthou, E., 2002. Ontogenetic diet shifts and interrupted piscivory in introduced largemouth bass (Micropterus salmoides). International Review of Hydrobiology 87, 353-363.

García-Berthou, E., 2007. The characteristics of invasive fishes: what has been learned so far? Journal of Fish Biology 71, 33-55.

García-Berhou, E., Moreno-Amich, R., 2000. Introduction of exotic fish into a Mediterranean lake over a 90-year period. Archiv für Hydrobiologie 271-284.

García-Murillo, P., Dana Sánchez, E., Rodríguez Hiraldo, C., 2005. Pistia stratiotes, L. (Araceae) una planta acuática exótica en las proximidades del Parque Nacional de Doñana (SW España). Acta Botanica Malacitana 30, 235-236.

García-Novo, F., Marín, C., 2005. Doñana. Water and biosphere. Doñana 2005, Confederación Hidrográfica del Guadalquivir, Ministerio de Medio Ambiente, Madrid, España.

Garrido, H., Saénz de Buruaga, M., 2002. Introducción de especies alóctonas: la malvasía en el 
Mediterráneo occidental. U. T. E CRN Sylvatica, Almonte, Huelva, España.

GEIB., 2006. TOP 20: Las 20 especies exóticas invasoras más dañinas presentes en España. GEIB, Serie Técnica N 2, León, España.

Geiger, W., Alcorlo, P., Baltanás, A., Montes, C., 2005. Impact of an introduced Crustacean on the trophic webs of Mediterranean wetlands. Biological Invasions 7, 49-73.

Genovesi, P., Bertolino, S., 2001. Human dimension aspects in invasive alien species issues: the case of the failure of the grey squirrel eradication project in Italy, in: McNeely, J.A. (Ed.), The Great Reshuffling: Human dimensions of invasive alien species. IUCN, Gland, Switzerland/Cambridge, UK, pp. 113-119.

Gratwicke, B., Marshal, B. E., 2001. The impact of Azolla filiculoides Lam. on animal biodiversity in streams in Zimbabwe. African Journal of Ecology 39, 216-218.

Greene, W.H., 2000. Econometric Analysis, 4th edition. Prentice-Hall International, New Jersey, USA.

Gómez-Caruana, F., Díaz-Luna, J.L., 1991. Guía de los peces continentales de la Península Ibérica. Acción Divulgativa, S.L, Madrid, España.

Gómez-Limón, J., Medina Domingo, L., Atance Muñoz, I., Garrido Palomero, A., 2003. Los visitantes de la comarca de Doñana. Sostenible 4, 1-113.

Habsburgo-Lorena, A.S., 1986. The status of the Procambarus clarkii population in Spain. Freshwater Crayfish 6, 131-136.

Hulme, P.E., 2006. Beyond control: wider implications for the management of biological invasions. Journal of Applied Ecology 43, 835-847.

Jetter, K., Paine, T. D., 2004. Consumer preferences and willingness to pay for biological control in the urban landscape. Biological Control 30, 312-322.

Jiménez-Pérez, I., Delibes de Castro, M., 2005. Al borde de la extinción. Una visión integral de la recuperación de fauna amenazada en España. EVREN, Evaluación de Recursos Naturales, 
Valencia, España.

Keller, R.P., Lodge, D.M., 2007. Species invasions from commerce in live aquatic commerce in live aquatic organisms: problems and possible solutions. BioScience 57, 428-436.

Kendle, A.D., Rose, J.E., 2000. The aliens have landed! What are the justifications for 'native only' policies in landscape plantings? Landscape Urban Plan 47, 19-31.

Kennedy, J.J., 1985. Viewing wildlife managers as a unique professional culture. Wildlife Society Bulletin 13, 571-579.

Lovell, S.J., Stone, S.F., 2005. The Economic Impacts of Aquatic Invasive Species: A Review of the Literature. Working paper 2005-02. U.S. Environmental Protection Agency National Center for Environmental Economics. [online] URL: http://www.epa.gov/economics

Lowe, S., Browne, M., Boudjelas, S., De Poorter, M., 2004. 100 of the World's Worst Invasive Alien Species. A selection from the Global Invasive Species Datatabase. The Invasive Species Specialist Group (ISSG), a specialist group of the Species survival Commission (SSC) of the World Conservation Union (IUCN) (Eds.), Auckland, New Zealand.

Lozano-Rey, L., 1935. Los peces fluviales de España. Memoria Real Academia de Ciencias Exactas, Físicas y Naturales 11, 1-839.

Mack, R.N., Simberloff, D., Lonsdale, W.M., Evans, H., Clout, M., Bazzaz, F., 2000. Biotic invasions: causes, epidemiology, global consequences and control. Issues in Ecology 5.

Madroño, A., González, C., Atienza, J.C., 2004. Libro Rojo de las aves de España. Ministerio de Medio Ambiente, SEO/BirdLife, Madrid, España.

Martín-López, B., Montes, C., Benayas, J., 2007. Influence of user characteristics on valuation of ecosystem services in Doñana natural protected area (south-west Spain). Environmental Conservation $34,215-224$

McNeely, J. A., 2001. The Great Reshuffling: Human dimensions of invasive alien species. IUCN, Gland, Switzerland/Cambridge, UK. 
Meerhoff, M., Mazzeo, N., 2004. Importancia de las plantas flotantes libres de gran porte en la conservación y rehabilitación de lagos someros de Sudamérica. Ecosistemas 2.

Meyerson, L.A., Money, H., 2007. Invasive alien species in an era of globalization. Frontiers in Ecology and the Environment 5, 199-208.

Miller, S. A., Crowl, T.A., 2006. Effects on common carp (Cyprinus carpio) on macrophytes and invertebrate communities in a shallow lake. Freshwater Biology 51, 85-94.

Mitchell, R.C., Carson, R.T., 1989. Using Survey to Value Public Goods. The Contingent Valuation Method. Resources for the Future, Washington D.C., USA.

Mooney, H.A., Mack, R.N., McNeely, J.A., Neville, L.E., Schei, P.J., Waage, J.K., 2005. Invasive alien species. A new synthesis. Island Press, Washington D.C., USA.

Montes, C., Borja, F., Bravo, M.A., Moreira, J.M., 1998. Reconocimiento Biofísico de Espacios Naturales Protegidos. Doñana: Una Aproximación Ecosistémica. Consejería de Medio Ambiente, Junta de Andalucía, Sevilla, España.

Perrings, C., Dehnen-Schmutz, K., Touza, J., Williamson, M., 2005. How to manage biological invasions under globalization. Trends in Ecology and Evolution 20, 212-215.

Perrings, C., Williamson, M., Barbier, E.B., Delfino, D., Dalmazzone, S., Shogren, J., Simmons, P., Watkinson, A., 2002. Biological Invasion Risks and the Public Good: an Economic Perspective. Conservation Ecology 6, 1. [online] URL: http://www.consecol.org/vol6/iss1/art1

Perrings, C., Williamson, M., Dalmazzone, S., 2000. The Economics of Biological Invasions. Edward Elgar, Cheltenham, UK.

Philip, L.J., Macmillan, D.C., 2005. Exploring values, context and perceptions in contingent valuation studies: the CV Market Stall Technique and willingness to pay for wildlife conservation. Journal of Environmental Planning and Management 48, 257-274.

Pimentel, D., 2002. Biological invasions: economic and environmental cost of alien plant, animal and microbe species. CRC Press LLC, USA. 
Pimentel, D., Zuniga, R., Morrison, D., 2005. Update on the environmental and economic costs associated with alien-invasive species in the United State. Ecological Economics 52, 273-288.

Pleguezuelos, J.M., Márquez, R., Lizana, M.E., 2002. Atlas y Libro Rojo de los Anfibios y Reptiles de España. Dirección General de Conservación de la Naturaleza-Asociación Herpetológica Española, Madrid, España.

Requena, S., 1998. La valoración del paisaje por 'público y expertos'. Aplicaciones a la participación ciudadana en la gestión ambiental. Universidad Autónoma de Madrid. Madrid, España.

Rivas-Martínez, S., Costa, M., Castroviejo, S., Valdés, E., 1980. Vegetación de Doñana (Huelva, España). Lazaroa 2, 5-190.

Sala, O., Chapin, S., Armesto, J., Berlow, E., Bloomfield, J., Dirzo, R., Huber-Sanwald, E., Huenneke, L., Jackson, R., Kinzig, A., Leemans, R., Lodge, D., Mooney, H., Oesterheld, M., Leroy Poff, N., Sykes, M., Walker, B., Walker, M., Wall, D., 2000. Global biodiversity scenarios for the year 2100. Science 287, 1770-1774.

Sigelman, L., Zeng, L., 1999. Analyzing censored and sample selected data with Tobit and Heckit models. Political Analysis 8, 167-182.

Simberloff, D., 2003. How much information on population biology is needed to manage introduced species? Conservation Biology 17, 83-92.

Simberloff, D., 2005. The politics of assessing risk for biological invasions: the USA as a case study. Trends in Ecology and Evolution 20, 216-222.

Smith, K.G., Darwall, W.R.T., 2006. The Status and Distribution of Freshwater Fish Endemic to the Mediterranean Basin. IUCN, Gland, Switzerland/Cambridge, UK.

Stokes, K.E., O’Neill, K.P., Montgomery, W.I., Dick, J.T.A., Maggs, C.A., Mcdonald, R.A., 2006. The importance of stakeholder engagement in invasive species management: a crossjurisdictional perspective in Ireland. Biodiversity and Conservation 15, 2829-2852. 
Tavares, K., 1997. Big island melastome action committee: Miconia calvescens control program overview. Proceedings of the First Regional Conference on Miconia Control. pp. 52-64.

Veall, M.R., Zimmermann, K.F., 1992. Pseudo-R2s in the Ordinal Probit model. Journal of Mathematical Sociology 16, 333-342.

Wittenberg, R., Cock, M.J.W., 2001. Invasive alien species. How to address one of the greatest threats to biodiversity: A toolkit of best prevention and management practices. $C A B$ International, Wallingford, Oxon, UK.

Zavaleta, E.S., Hobbs, R.J., Mooney, H.A., 2001. Viewing invasive species removal in wholeecosystem context. Trends in Ecology and Evolution 16, 454-459. 
735 Table 1. List of species selected considering ecological, social and management factors. $\mathrm{C}=$ Competition; $\mathrm{P}=$ Predation; $\mathrm{H}=\mathrm{Hybridization;} \mathrm{G.C.=} \mathrm{Geotic}$ 736 control; E.C. = Eradication and/or control programs; $\mathrm{R}=$ Research programs; Ed. = Educational programs; D.T. = Disease transmission.

\begin{tabular}{|c|c|c|c|c|c|c|c|c|c|c|c|c|c|c|}
\hline \multicolumn{3}{|c|}{ Non-native invasive species } & \multicolumn{4}{|c|}{ Ecological factors } & \multicolumn{5}{|c|}{ Management factors } & \multicolumn{3}{|l|}{ Social factors } \\
\hline Latin name & Common name & Origin & $\mathrm{C}$ & $\mathrm{P}$ & $\mathrm{H}$ & G.C. & $\begin{array}{l}\text { Endangered } \\
\text { species }\end{array}$ & $\begin{array}{l}\text { UICN } \\
\text { list }\end{array}$ & E.C. & $\mathrm{R}$ & Ed & $\begin{array}{l}\text { Socioeconomic } \\
\text { uses }\end{array}$ & $\mathrm{DT}$. & References \\
\hline \multicolumn{15}{|l|}{ Plants } \\
\hline Azolla filiculoides & Red waterfern & South America & $\checkmark$ & & & $\checkmark$ & & & $\checkmark$ & $\checkmark$ & & Rice fertilizer & & $\begin{array}{l}\text { Gratwicke and Marshall, 2001; de Macalel and Vlek, 2004; } \\
\text { Fernández-Zamudio et al., } 2006\end{array}$ \\
\hline Pistia stratiotes & Water lettuce & South America & $\checkmark$ & & & $\checkmark$ & & & $\checkmark$ & & & $\begin{array}{l}\text { Ornamental } \\
\text { Waste water } \\
\text { treatment } \\
\text { Bioindicator of } \\
\text { metals }\end{array}$ & & Meerhoff and Mazzeo, 2004; García-Murillo et al., 2005 \\
\hline Carpobrotus edulis & Ice plant & South Africa & $\checkmark$ & & & & $\begin{array}{l}\text { Limonium } \\
\text { emarginatum } \\
\text { Juniperus } \\
\text { oxycedrus }\end{array}$ & & $\checkmark$ & & $\checkmark$ & $\begin{array}{l}\text { Ornamental } \\
\text { Soil fixation } \\
\text { Medicinal plant }\end{array}$ & & $\begin{array}{l}\text { Blanca et al., 2000; CMA, 2003; Figueroa-Clemente, 2003; } \\
\text { Bañares et al., 2004; GEIB, } 2006\end{array}$ \\
\hline $\begin{array}{l}\text { Eucalyptus spp. } \\
\text { (E. globulus and } E \text {. } \\
\text { camaldulensis) }\end{array}$ & Eucalyptus & Australia & $\checkmark$ & & & $\checkmark$ & & & $\checkmark$ & & & $\begin{array}{l}\text { Apiculture/l } \\
\text { Wood } \\
\text { Medicinal plant }\end{array}$ & & Dana et al., 2005 \\
\hline \multicolumn{15}{|l|}{ Invertebrates } \\
\hline Procambarus clarkii & $\begin{array}{l}\text { Red swamp } \\
\text { crayfish }\end{array}$ & North America & $\checkmark$ & $\checkmark$ & & $\checkmark$ & & & & $\checkmark$ & & Food & $\checkmark$ & CPA, 2001; Madroño et al., 2004; Geiger et al., 2005 \\
\hline Eriocheir sinensis ${ }^{*}$ & $\begin{array}{l}\text { Chinese mitten } \\
\text { crab }\end{array}$ & China & & & & & & & $\checkmark$ & $\checkmark$ & $\checkmark$ & & $\checkmark$ & Lowe et al., 2004; GEIB, 2006 \\
\hline Linepithema humile & Argentine ant & Argentina & $\checkmark$ & & & & & $\checkmark$ & & $\checkmark$ & & & & $\begin{array}{l}\text { Carpintero et al., 2001; Lowe et al., 2004; Carpintero et al., } \\
2007\end{array}$ \\
\hline \multicolumn{15}{|l|}{ Vertebrates } \\
\hline Cyprinus carpio & Common carp & $\begin{array}{l}\text { Europe and } \\
\text { Asia }\end{array}$ & $\checkmark$ & $\checkmark$ & & $\checkmark$ & $\begin{array}{l}\text { Oxyura } \\
\text { leucocephala }\end{array}$ & $\checkmark$ & & & & $\begin{array}{l}\text { Recreational } \\
\text { fishing } \\
\text { Food }\end{array}$ & & $\begin{array}{l}\text { Gómez-Caruana and Díaz-Luna, 1991; Lowe et al., 2004; } \\
\text { Madroño et al., 2004; Jiménez-Pérez and Delibes de } \\
\text { Castro, 2005; Miller and Crowl, 2006; Garcia-Berthou, } 2007\end{array}$ \\
\hline $\begin{array}{l}\text { Fundulus } \\
\text { heteroclitus }\end{array}$ & Mummichog & North America & $\checkmark$ & $\checkmark$ & & & $\begin{array}{l}\text { Aphanius } \\
\text { baeticus }\end{array}$ & & & & & Aquarium fish & & $\begin{array}{l}\text { Gómez-Caruana and Díaz-Luna, 1991; Doadrio et al., } \\
\text { 2001; Smith and Darwall, } 2006\end{array}$ \\
\hline $\begin{array}{l}\text { Gambusia } \\
\text { holbrooki }\end{array}$ & Mosquitofish & North America & $\checkmark$ & $\checkmark$ & & & A. baeticus & $\checkmark$ & & & & $\begin{array}{l}\text { Biological } \\
\text { control agent }\end{array}$ & & $\begin{array}{l}\text { García-Berthou and Moreno-Amich 2000; Doadrio et al., } \\
\text { 2001; Smith and Darwall, } 2006\end{array}$ \\
\hline Lepomis gibbosus & Pumpkinseed & North America & $\checkmark$ & $\checkmark$ & & & & & & & & $\begin{array}{l}\text { Recreational } \\
\text { fishing }\end{array}$ & & Fernández-Delgado et al., 2000 \\
\hline $\begin{array}{l}\text { Micropterus } \\
\text { salmoides }\end{array}$ & $\begin{array}{l}\text { Largemouth } \\
\text { bass }\end{array}$ & North America & $\checkmark$ & $\checkmark$ & & & & $\checkmark$ & & & & $\begin{array}{l}\text { Recreational } \\
\text { fishing }\end{array}$ & & $\begin{array}{l}\text { Fernández-Delgado et al., 2000; García-Berthou, 2002; } \\
\text { Lowe et al., } 2004\end{array}$ \\
\hline
\end{tabular}

\footnotetext{
${ }^{*}$ Included in the attitudes and perception objectives of the study because of the social interest of this species among local people during the sampling. This was not selected for the economic valuation.
} 

$\begin{array}{ll}\text { Trachemys scripta } & \begin{array}{l}\text { Red-eared } \\ \text { slider turtle }\end{array}\end{array}$

North America

Emys orbicularis

Mauremys

O. leucocephala
Pleguezuelos, 2002; Lowe et al., 2004; GEIB, 2006

Garrido and Sáenz de Buruaga, 2002; Madroño et al., 2004 
Table 2. Summary of the non-parametric variables used in the analyses performed at different scales, their main attributes and the analysis for which they were used.

\begin{tabular}{|c|c|c|c|}
\hline Variables & Type & Attributes & Analysis \\
\hline \multicolumn{4}{|l|}{$\begin{array}{l}\text { Knowledge, perception and } \\
\text { attitudes variables }\end{array}$} \\
\hline IAS_MEANING & Dummy & $\begin{array}{l}\text { Definition of the term alien invasive } \\
\text { species ( } 1=\text { Knowledge of the meaning; } \\
0=\text { otherwise) }\end{array}$ & $\begin{array}{l}\text { Cluster analysis } \\
\text { Factor analysis } \\
\text { Heckit model (Probit) } \\
\text { Cluster analysis }\end{array}$ \\
\hline WILLING_INTRODUCE & Dummy & $\begin{array}{l}\text { Willingness to introduce an exotic species } \\
\text { ( } 1=\text { not willing to do it; } 0=\text { otherwise })\end{array}$ & $\begin{array}{l}\text { Factor analysis } \\
\text { Heckit model (Probit) } \\
\text { Heckit model (OLS) }\end{array}$ \\
\hline \multirow{2}{*}{ EXOTIC_KNOWN } & \multirow{2}{*}{ Ordinal } & Ln (Number of introduced species known) & $\begin{array}{l}\text { Cluster analysis } \\
\text { Factor analysis }\end{array}$ \\
\hline & & $\begin{array}{l}\text { Square root (Number of introduced } \\
\text { species known) }\end{array}$ & Heckit model (OLS) \\
\hline \multicolumn{4}{|l|}{ Role of IAS in Doñana SES } \\
\hline ECOSYSTEMS & Dummy & $1=$ threaten ecosystems; $0=$ otherwise & $\begin{array}{l}\text { Cluster analysis } \\
\text { Factor analysis } \\
\text { Cluster analysis }\end{array}$ \\
\hline ECONOMY & Dummy & $1=$ effect on economy; $0=$ otherwise & $\begin{array}{l}\text { Factor analysis } \\
\text { Heckit model (Probit) } \\
\text { Heckit model (OLS) } \\
\text { Cluster analysis }\end{array}$ \\
\hline DISEASE & Dummy & $1=$ disease transmission; $0=$ otherwise & $\begin{array}{l}\text { Cluster analysIS } \\
\text { Heckit model (Probit) } \\
\text { Heckit model (OLS) }\end{array}$ \\
\hline CULTURAL IDENTITY & Dummy & $1=$ effect on cultural identity; $0=$ otherwise & $\begin{array}{l}\text { Cluster analysis } \\
\text { Factor analysis }\end{array}$ \\
\hline WORK & Dummy & $1=$ effect on work; $0=$ otherwise & Heckit model (Probit) \\
\hline \multicolumn{4}{|c|}{ Environmental attitudes variables } \\
\hline - & Dummy & \multirow{2}{*}{$\begin{array}{l}\text { Member of environmental } N G O=1 \\
0=\text { otherwise } \\
\text { Ln (Number of visited other NPAs the last } \\
\text { year) }\end{array}$} & $\begin{array}{l}\text { Cluster analysis } \\
\text { Factor analysis } \\
\text { Heckit model (Probit) } \\
\text { Heckit model (OLS) }\end{array}$ \\
\hline \multirow[b]{2}{*}{ NPAs } & \multirow[b]{2}{*}{ Ordinal } & & Cluster analysis \\
\hline & & $\begin{array}{l}\text { Square root (Number of visited other } \\
\text { NPAs the last year) }\end{array}$ & $\begin{array}{l}\text { Factor analysis } \\
\text { Heckit model (Probit) } \\
\text { Heckit model (OLS) }\end{array}$ \\
\hline \multicolumn{4}{|l|}{ Socioeconomic variables } \\
\hline \multirow[t]{2}{*}{ DISTANCE } & \multirow[t]{2}{*}{ Continuous } & $\begin{array}{l}\text { Ln (Distance from place of residence to } \\
\text { the interview place (kilometres)) }\end{array}$ & $\begin{array}{l}\text { Factor analysis } \\
\text { Heckit model (Probit) } \\
\text { Heckit model (OLS) }\end{array}$ \\
\hline & & $\begin{array}{l}\text { Ln (Education level }(0=\text { none; } 1=\text { primary; } \\
2=\text { secondary; } 3=\text { =university }) \text { ) }\end{array}$ & Cluster analysis \\
\hline EDUCATION & Ordinal & $\begin{array}{l}\text { Education level }(0=\text { none; } 1=\text { primary; } \\
2=\text { secondary; } 3=\text { university })\end{array}$ & $\begin{array}{l}\text { Factor analysis } \\
\text { Heckit model (Probit) } \\
\text { Heckit model (OLS) }\end{array}$ \\
\hline GENDER & Dummy & $1=$ male $; 0=$ female & Heckit model (OLS) \\
\hline AGE & Continuous & Ln (Age (years)) & Heckit model (Probit) \\
\hline HOUSESIZE & Ordinal & Household size (members) & $\begin{array}{l}\text { Heckit model (Probit) } \\
\text { Heckit model (OLS) }\end{array}$ \\
\hline INCOME & $\begin{array}{l}\text { Semi- } \\
\text { continuous }\end{array}$ & $\begin{array}{l}\text { Ln (Monthly family income which reflected } \\
\text { the mid-point of six income intervals }(0- \\
900 €=600 € ; 900-1500 €=1200 € ; 1500-2 \\
100=1800 € ; 2100-2700 €=2400 € ; 2 \\
700-3300=3000 € ; \geq 3300=3600 €) \\
(1 €=\text { US } \$ 1.32 \text {, average June } 2006-\text { Sep } \\
2007)\end{array}$ & $\begin{array}{l}\text { Heckit model (Probit) } \\
\text { Heckit model (OLS) }\end{array}$ \\
\hline
\end{tabular}

\section{Other variables}

ATTITUDE

Ordinal

UNDERSTANDING
Respondent's attitude towards the questionnaire (1=not receptive; 2 = indifferent; $3=$ receptive)

Respondent's understanding of the questionnaire (1=low; $2=$ regular, $3=$ high $)$
Heckit model (Probit) Heckit model (OLS)

Heckit model (Probit) Heckit model (OLS) 
739 Table 3. Characterization of the five stakeholder groups obtained in the cluster analysis based on knowledge and perception of the impacts of IAS,

740 attitudes toward the introduction of IAS and IAS management, environmental behavior and socioeconomic variables. E. H. = economically harmful

741 because of the effect on provisioning ecosystem services; $\mathrm{E}$. = damage to ecosystems; $\mathrm{B}$ = damage to biodiversity because of the effect on rights of

742 existence of the species threatened by alien species.

743

\begin{tabular}{|c|c|c|c|c|c|c|c|c|c|c|c|}
\hline \multirow{2}{*}{$\begin{array}{l}\text { Stakeholders } \\
(\%)\end{array}$} & \multicolumn{4}{|c|}{ Knowledge and perception of the impact of IAS } & \multicolumn{2}{|c|}{$\begin{array}{l}\text { Attitudes toward the } \\
\text { introduction of IAS and } \\
\text { their management }\end{array}$} & \multicolumn{2}{|c|}{$\begin{array}{l}\text { Environmental } \\
\text { behaviour }\end{array}$} & \multicolumn{3}{|c|}{ Socioeconomic variables } \\
\hline & $\begin{array}{l}\text { IAS_ME } \\
\text { ANING }{ }^{*}\end{array}$ & EXOTIC_KNOWN & $\begin{array}{l}\text { Most impact } \\
\text { species }^{\dagger}\end{array}$ & $\begin{array}{l}\text { Role of IAS in } \\
\text { Doñana SES }\end{array}$ & $\begin{array}{l}\text { Motives for } \\
\text { management }\end{array}$ & $\begin{array}{l}\text { WILLING_IN } \\
\text { TRODUCE* }\end{array}$ & $\mathrm{NPAs}^{*}$ & NGO * & $\begin{array}{l}\text { Place of } \\
\text { residence }\end{array}$ & $\begin{array}{l}\text { EDUCATIO } \\
\mathrm{N}\end{array}$ & $\begin{array}{l}\text { INCOME (1€=US\$ } \\
\text { 1.32, average June } \\
\text { 2006-Sep 2007) }\end{array}$ \\
\hline $\begin{array}{l}\text { Local users } \\
(20 \%)\end{array}$ & $52 \%$ & Procambarus clarkii & P. clarkii & $\begin{array}{l}\text { ECONOMY } \\
\text { DISEASE }\end{array}$ & $\begin{array}{l}\mathrm{E} . \mathrm{H} . \\
\mathrm{E}\end{array}$ & $32 \%$ & $33 \%$ & $2 \%$ & $\begin{array}{l}\text { Doñana } \\
\text { Huelva-Seville- } \\
\text { Cádiz }\end{array}$ & $\begin{array}{l}\text { Primary } \\
\text { Secondary }\end{array}$ & $900-1500 €$ \\
\hline $\begin{array}{l}\text { Generalist } \\
\text { tourists } \\
(18 \%)\end{array}$ & $33 \%$ & P. clarkii & $\begin{array}{l}\text { P. clarkii } \\
\text { Eucalyptus spp. } \\
\text { T. scripta }\end{array}$ & $\begin{array}{l}\text { ECOSYSTEM } \\
\text { S }\end{array}$ & $\begin{array}{l}\mathrm{E} \\
\mathrm{By}\end{array}$ & $60 \%$ & $45 \%$ & $5 \%$ & $\begin{array}{l}\text { Doñana } \\
\text { Huelva-Seville- } \\
\text { Cádiz } \\
\text { Spain }\end{array}$ & Secondary & $900-1500 €$ \\
\hline $\begin{array}{l}\text { Nature tourists } \\
(35 \%)\end{array}$ & $100 \%$ & $\begin{array}{l}\text { P. clarkii } \\
\text { Carpobrotus edulis } \\
\text { Eucalyptus spp. } \\
\text { Trachemys scripta }\end{array}$ & $\begin{array}{l}\text { P. clarkii } \\
\text { C. edulis } \\
\text { Eucalyptus spp. } \\
\text { T. scripta } \\
\text { A. filiculoides }\end{array}$ & $\begin{array}{l}\text { ECOSYSTEM } \\
\text { S }\end{array}$ & $\mathrm{E}$ & $0 \%$ & $62 \%$ & $0 \%$ & $\begin{array}{l}\text { Huelva-Seville- } \\
\text { Cádiz } \\
\text { Spain }\end{array}$ & $\begin{array}{l}\text { Secondary } \\
\text { University }\end{array}$ & $\begin{array}{l}900-1500 € \\
1500-2100 €\end{array}$ \\
\hline $\begin{array}{l}\text { Conservation } \\
\text { professionals- } \\
\text { group } 1(13 \%)\end{array}$ & $83 \%$ & $\begin{array}{l}\text { P. clarkii } \\
\text { C. edulis } \\
\text { Eucalyptus spp. } \\
\text { T. scripta } \\
\text { Azolla filiculoides }\end{array}$ & $\begin{array}{l}\text { P. clarkii } \\
\text { C. edulis } \\
\text { Eucalyptus spp. } \\
\text { T. scripta } \\
\text { A. filiculoides }\end{array}$ & $\begin{array}{l}\text { ECOSYSTEM } \\
\text { S } \\
\text { ECONOMY } \\
\text { CULTURAL } \\
\text { IDENTITY }\end{array}$ & $\begin{array}{l}\text { E.H. } \\
\mathrm{E}\end{array}$ & $7 \%$ & $80 \%$ & $30 \%$ & $\begin{array}{l}\text { Huelva-Seville- } \\
\text { Cádiz } \\
\text { Spain }\end{array}$ & University & $1500-2100 €$ \\
\hline $\begin{array}{l}\text { Conservation } \\
\text { professionals- } \\
\text { group } 2 \text { (14\%) }\end{array}$ & $94 \%$ & $\begin{array}{l}\text { P. clarkii } \\
\text { C. edulis } \\
\text { Eucalyptus spp. } \\
\text { T. scripta } \\
\text { A. filiculoides } \\
\text { Eriocheir sinensis } \\
\text { Linepithema humile } \\
\text { Nicotiana glauca }\end{array}$ & $\begin{array}{l}\text { P. clarkii } \\
\text { C. edulis } \\
\text { Eucalyptus spp. } \\
\text { T. scripta } \\
\text { A. filiculoides } \\
\text { Cyprinus carpio } \\
\text { Oxyura jamaicensis }\end{array}$ & $\begin{array}{l}\text { ECOSYSTEM } \\
\text { S }\end{array}$ & $\mathrm{E}$ & $0 \%$ & $88 \%$ & $100 \%$ & $\begin{array}{l}\text { Huelva-Seville- } \\
\text { Cádiz } \\
\text { Spain }\end{array}$ & University & $1500-2100 €$ \\
\hline
\end{tabular}

* Percentage of stakeholders in each category.

† Species selected by more than $30 \%$ of the stakeholders in each category

* Role of the IAS in Doñana SES selected by more than $25 \%$ of the stakeholders in each category.

$\S$ Motives for management of IAS selected by more than $25 \%$ of the stakeholders in each category.

${ }^{* * *}$ Place of residence for more than $20 \%$ of the stakeholders in each category. 
Table 4. Factor loadings of the PCA results for stakeholder characterization.

\begin{tabular}{|c|c|c|c|c|}
\hline \multirow[b]{2}{*}{ Variables } & \multicolumn{2}{|l|}{ Factor scores } & \multicolumn{2}{|r|}{746} \\
\hline & $\begin{array}{l}\text { F1:environmental } \\
\text { behavior and IAS } \\
\text { knowledge }\end{array}$ & F2: role of IAS & $\begin{array}{l}\text { F3: sen } \\
\text { place }\end{array}$ & $\begin{array}{l}747 \\
748 \\
749\end{array}$ \\
\hline DISTANCE & 0.133 & -0.504 & 0.600 & 750 \\
\hline IAS_MEANING & 0.617 & 0.060 & -0.402 & 751 \\
\hline WILLING_INTRODUCE & -0.518 & 0.232 & -0.171 & 752 \\
\hline EXOTIC_KNOWN & 0.660 & 0.374 & -0.337 & 753 \\
\hline ECOSYSTEMS & 0.610 & -0.461 & -0.233 & 754 \\
\hline ECONOMY & -0.061 & 0.758 & 0.070 & 755 \\
\hline CULTURAL IDENTITY & 0.140 & 0.504 & 0.531 & $\begin{array}{l}756 \\
757\end{array}$ \\
\hline NGO & 0.566 & 0.144 & 0.150 & $\begin{array}{l}151 \\
758\end{array}$ \\
\hline NPAs & 0.649 & 0.191 & 0.279 & 759 \\
\hline EDUCATION & 0.697 & -0.064 & 0.155 & 760 \\
\hline Stakeholders & & & & 761 \\
\hline Local users & -0.538 & 0.363 & 0.031 & 762 \\
\hline Generalist tourists & -0.360 & -0.248 & -0.009 & 763 \\
\hline Nature tourists & 0.223 & -0.462 & -0.307 & $\begin{array}{l}104 \\
765\end{array}$ \\
\hline Conservation professionals-group 1 & 0.240 & 0.571 & 0.385 & 766 \\
\hline Conservation professionals-group 2 & 0.486 & -0.059 & 0.027 & 767 \\
\hline Eigenvalue & 2.72 & 1.55 & 1.13 & 768 \\
\hline Percentage variance explained & 27.23 & 15.54 & 11.30 & 769 \\
\hline
\end{tabular}


Table 5. Probit regression results regarding willingness to pay (WTP) or not to pay for IAS eradication (first stage of Heckit model). Dependent variable: 0 when WTP $=0$ and 1 when WTP $>0 . n=464$, significance ${ }^{* *}=1 \%,{ }^{* *}=5 \%$ and ${ }^{*}=10 \%$.

\begin{tabular}{|c|c|c|}
\hline Variables & Coefficient & $\begin{array}{r}775 \\
\text { t-value } 76\end{array}$ \\
\hline DISTANCE & $0.062^{* *}$ & 2.429778 \\
\hline IAS_MEANING & -0.113 & -0.692779 \\
\hline WILLING_INTRODUCE & -0.218 & $-1.224 \frac{780}{781}$ \\
\hline ECONOMY & $-0.295^{*}$ & -1.670782 \\
\hline DISEASE & $-0.327^{*}$ & -1.756783 \\
\hline WORK & -0.303 & -0.881785 \\
\hline NGO & 0.162 & $\begin{array}{l}0.945786 \\
787\end{array}$ \\
\hline NPAs & -0.032 & -0.416788 \\
\hline EDUCATION & $-0.146^{*}$ & -1.678790 \\
\hline AGE & $-0.521^{* * *}$ & $\begin{array}{r}-2.708791 \\
792\end{array}$ \\
\hline INCOME & 0.099 & 0.835793 \\
\hline HOUSESIZE & $-0.169^{* \star *}$ & $\begin{array}{r}-2.733^{794} \\
795\end{array}$ \\
\hline ATTITUDE & $0.423^{\star \star *}$ & $\begin{array}{r}3.309796 \\
797\end{array}$ \\
\hline UNDERSTANDING & 0.191 & $\begin{array}{r}798 \\
1.468799\end{array}$ \\
\hline Log likelihood & -284.69 & 801 \\
\hline Chi-square & 53.85 & 802 \\
\hline Pseudo- $R^{2}$ & 0.18 & $\begin{array}{l}803 \\
804\end{array}$ \\
\hline$p$-value & $<0.10$ & $\begin{array}{l}805 \\
806\end{array}$ \\
\hline$\%$ correct predictions & $81 \%$ & 807 \\
\hline
\end{tabular}


Table 6. Sample selection for the two-stage least squares regression results (second stage of Heckit model). Dependent variable: Ln (WTP), $n=464$, significance ${ }^{* *}=1 \%$ and ${ }^{*}=10 \%$.

\begin{tabular}{|c|c|c|c|}
\hline Variables & Coefficient & t-value & $\begin{array}{l}812 \\
813\end{array}$ \\
\hline CONSTANT & -2.500 & 0.001 & 815 \\
\hline \multirow[t]{2}{*}{ DISTANCE } & $0.109^{* * *}$ & 5.979 & 817 \\
\hline & & & 818 \\
\hline \multirow[t]{2}{*}{ WILLING_INTRODUCE } & -0.164 & -1.244 & 819 \\
\hline & & & 820 \\
\hline EXOTIC_KNOWN & 0.074 & 1.190 & $\begin{array}{l}821 \\
822\end{array}$ \\
\hline \multirow[t]{2}{*}{ ECONOMY } & $-0.370^{\star * *}$ & -3.071 & 823 \\
\hline & & & 825 \\
\hline \multirow[t]{2}{*}{ DISEASE } & -0.192 & -1.491 & 826 \\
\hline & & 1470 & 827 \\
\hline NGO & 0.101 & 1.470 & $\begin{array}{l}828 \\
829\end{array}$ \\
\hline \multirow[t]{2}{*}{ NPAs } & -0.056 & -0.941 & 830 \\
\hline & & & 831 \\
\hline \multirow[t]{2}{*}{ EDUCATION } & $-0.103^{*}$ & -1.602 & 832 \\
\hline & & & 834 \\
\hline \multirow[t]{2}{*}{ INCOME } & $0.277^{* * *}$ & 2.631 & 835 \\
\hline & & & 836 \\
\hline \multirow[t]{2}{*}{ HOUSESIZE } & $-0.363^{* * *}$ & -7.758 & 837 \\
\hline & & & 838 \\
\hline \multirow[t]{2}{*}{ GENDER } & -0.151 & -1.525 & 839 \\
\hline & & & 841 \\
\hline ATTITUDE & $0.376^{\star \star \star}$ & 3.685 & 842 \\
\hline \multirow{2}{*}{ UNDERSTANDING } & $0.401^{* * *}$ & 4.231 & 844 \\
\hline & & & 845 \\
\hline \multirow{2}{*}{ Inverse Mill's Ratio } & -3.000 & 0.001 & 846 \\
\hline & & & 847 \\
\hline Log likelihood & -645.22 & & 848 \\
\hline & & & 849 \\
\hline Adjusted $\mathrm{R}^{2}$ & 0.75 & & 850 \\
\hline
\end{tabular}


853 Table 7. Mean scores and F-values (ANOVA) for WTP for IAS eradication (1 $€=$ US $\$ 1.32$,

854 average June 2006 - Sep 2007), $n=439$, significance ${ }^{* * *}=1 \%,{ }^{* *}=5 \%$ and ${ }^{*}=10 \%$.

855

\begin{tabular}{|c|c|c|c|c|c|c|c|c|c|c|c|c|c|}
\hline \multirow{2}{*}{$\begin{array}{l}\text { Species (in order to } \\
\text { WTP for total users) }\end{array}$} & \multicolumn{2}{|c|}{ Total users } & \multicolumn{2}{|c|}{ Local users } & \multicolumn{2}{|c|}{$\begin{array}{l}\text { Generalist } \\
\text { tourists }\end{array}$} & \multicolumn{2}{|c|}{ Nature tourists } & \multicolumn{2}{|c|}{$\begin{array}{l}\text { Conservation } \\
\text { professionals- } \\
\text { group } 1\end{array}$} & \multicolumn{2}{|c|}{$\begin{array}{l}\text { Conservation } \\
\text { professionals- } \\
\text { group } 2\end{array}$} & \multirow[t]{2}{*}{ F-value } \\
\hline & Mean & $\begin{array}{l}\text { Std } \\
\text { dev. }\end{array}$ & Mean & $\begin{array}{l}\text { Std } \\
\text { dev. }\end{array}$ & Mean & $\begin{array}{l}\text { Std } \\
\text { dev. }\end{array}$ & Mean & $\begin{array}{l}\text { Std } \\
\text { dev. }\end{array}$ & Mean & $\begin{array}{l}\text { Std } \\
\text { dev. }\end{array}$ & Mean & $\begin{array}{l}\text { Std } \\
\text { dev. }\end{array}$ & \\
\hline Cyprinus carpio & 3.77 & 0.50 & 3.08 & 0.94 & 3.36 & 1.12 & 4.47 & 0.94 & 1.89 & 0.91 & 5.47 & 1.67 & 1.109 \\
\hline Freshwater plants ${ }^{*}$ & 3.54 & 0.55 & 1.79 & 0.70 & 2.54 & 0.85 & 4.40 & 1.05 & 4.91 & 2.14 & 4.34 & 1.73 & 1.190 \\
\hline Eucalyptus spp. & 3.21 & 0.57 & 0.95 & 0.66 & 2.96 & 1.19 & 3.78 & 1.03 & 5.48 & 2.35 & 3.72 & 1.64 & 1.460 \\
\hline Procambarus clarkii & 2.58 & 0.38 & 1.19 & 0.53 & 3.19 & 0.99 & 2.80 & 0.67 & 2.59 & 1.08 & 3.49 & 1.21 & 1.074 \\
\hline Gambusia holbrooki & 2.77 & 0.41 & 1.64 & 0.81 & 2.80 & 0.95 & 3.95 & 0.84 & 0.85 & 0.52 & 3.30 & 1.00 & $1.854^{*}$ \\
\hline Carpobrotus edulis & 1.77 & 0.33 & 0.31 & 0.25 & 1.97 & 0.76 & 1.61 & 0.48 & 2.27 & 1.27 & 3.93 & 1.34 & $2.644^{* *}$ \\
\hline Trachemys scripta & 1.58 & 0.29 & 0.15 & 0.11 & 1.02 & 0.57 & 1.55 & 0.46 & 2.34 & 1.06 & 4.19 & 1.26 & $4.537^{* * *}$ \\
\hline Other fishes $^{\dagger}$ & 1.58 & 0.29 & 0.15 & 0.11 & 1.02 & 0.57 & 1.55 & 0.46 & 2.34 & 1.06 & 4.19 & 1.26 & $4.537^{* * *}$ \\
\hline
\end{tabular}

856

\footnotetext{
* Referring to: Azolla filiculoides and Pistia stratiotes because of their similar ecological roles.

${ }^{\dagger}$ Referring to: Fundulus heteroclitus, Lepomis gibbosus, Micropterus salmoides because sampling assessed these species to have similar roles.
} 
Table 8. Factor loading produced by the CCA for the relationships between stakeholders and their WTP for eradication of particular species.

\begin{tabular}{lllr}
\hline Species & CCA Standard coefficients & \multicolumn{2}{r}{860} \\
& F1: Eradication v/s research & \multicolumn{2}{c}{ F2: Popularity-th86atl } \\
& -0.536 & 1.248 & 862 \\
\hline Freshwater plants & 1.433 & -1.427 & 863 \\
C. edulis & -0.075 & 1.566 & 865 \\
Eucalyptus spp. & -0.401 & 0.035 & 866 \\
P. clarkii & -0.689 & -0.584 & 867 \\
L. humile & -0.910 & -0.442 & 868 \\
C. carpio & -0.987 & -0.437 & 869 \\
G. holbrooki & 1.984 & 0.835 & 870 \\
Other fishes & 1.984 & 0.835 & 871 \\
T. scripta & 0.721 & -1.446 & 872 \\
O. jamaicensis & & & 874 \\
\hline Stakeholders & -0.469 & -0.273 & 875 \\
Local users & -0.200 & -0.287 & 876 \\
Generalist tourists & -0.515 & 0.470 & 877 \\
Nature tourists & 0.544 & 0.667 & 878 \\
Conservation professionals-group 1 & 0.672 & -0.664 & 879 \\
Conservation professionals-group 2 & 0.069 & 0.031 & 880 \\
\hline Eigenvalue & 58.59 & 26.32 & 881 \\
Percentage variance explained & 3.170 & & 883 \\
Total inertia & & & 884 \\
\hline
\end{tabular}


Fig. 1. Location of the Doñana SES and sample points.

Fig. 2. Cluster analysis for the categorization of stakeholder groups related to: degree of knowledge, perception and attitudes towards IAS, environmental attitudes and socioeconomic variables. Five stakeholder groups were categorized with a coefficient of dissimilarity of 0.67 . Fig. 3. Relationship between the percentage of people that knew about the introduction of a species and the period of its introduction for five exotic species in Doñana SES.

Fig. 4. Ordination diagram produced by the CCA showing the relationship between stakeholders and their WTP for eradication of particular species. 
- SAMPLE POINTS

\section{PROTECTED AREAS}

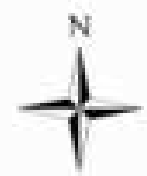

Doh̄ana National Park

sunas. Don̂ana Natural Park

\section{ECODISTRICTS}

Aeolian Sheets

zaz Marshes

Coastal System

Guadalquivir Estuary

Urban areas

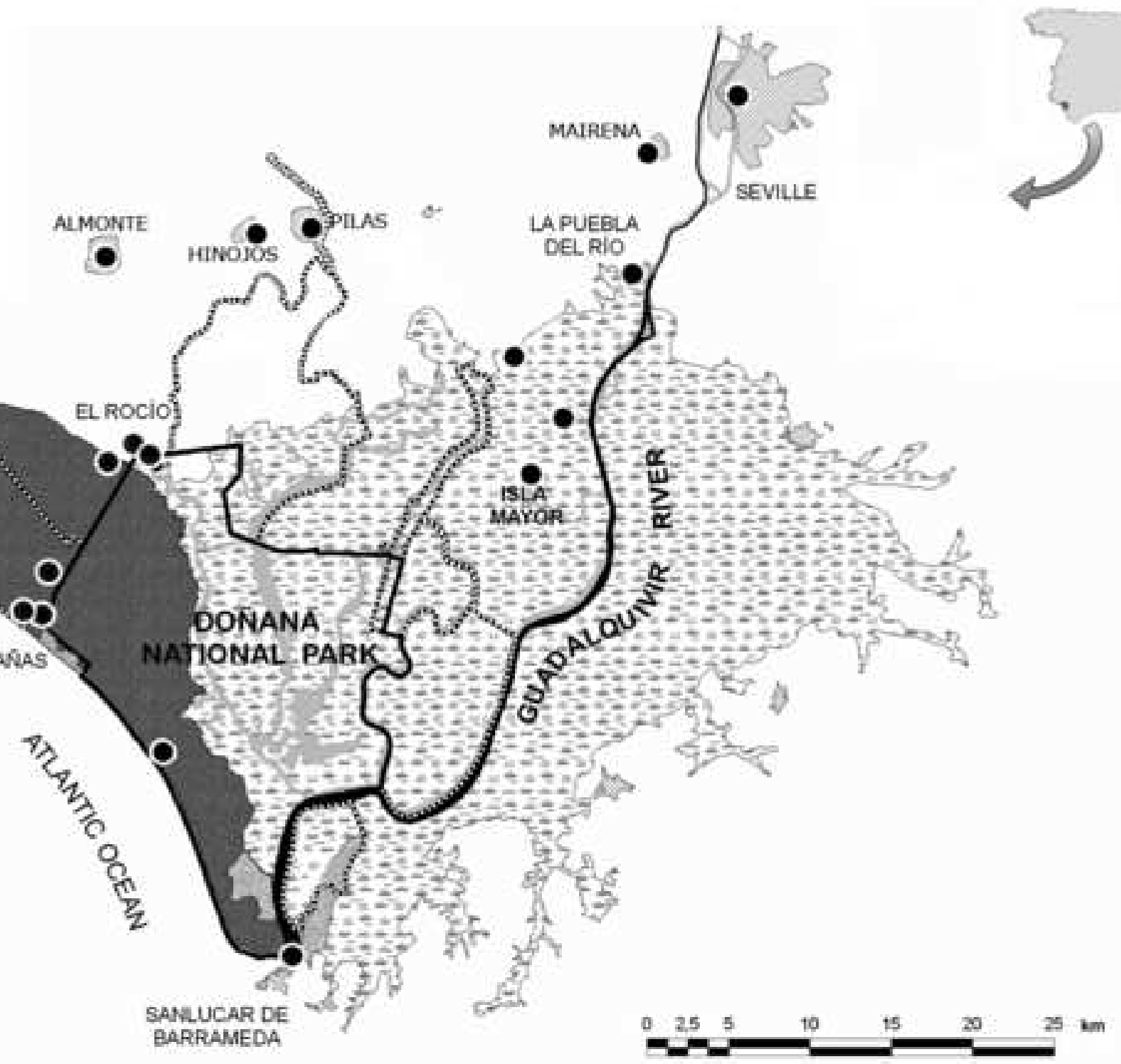




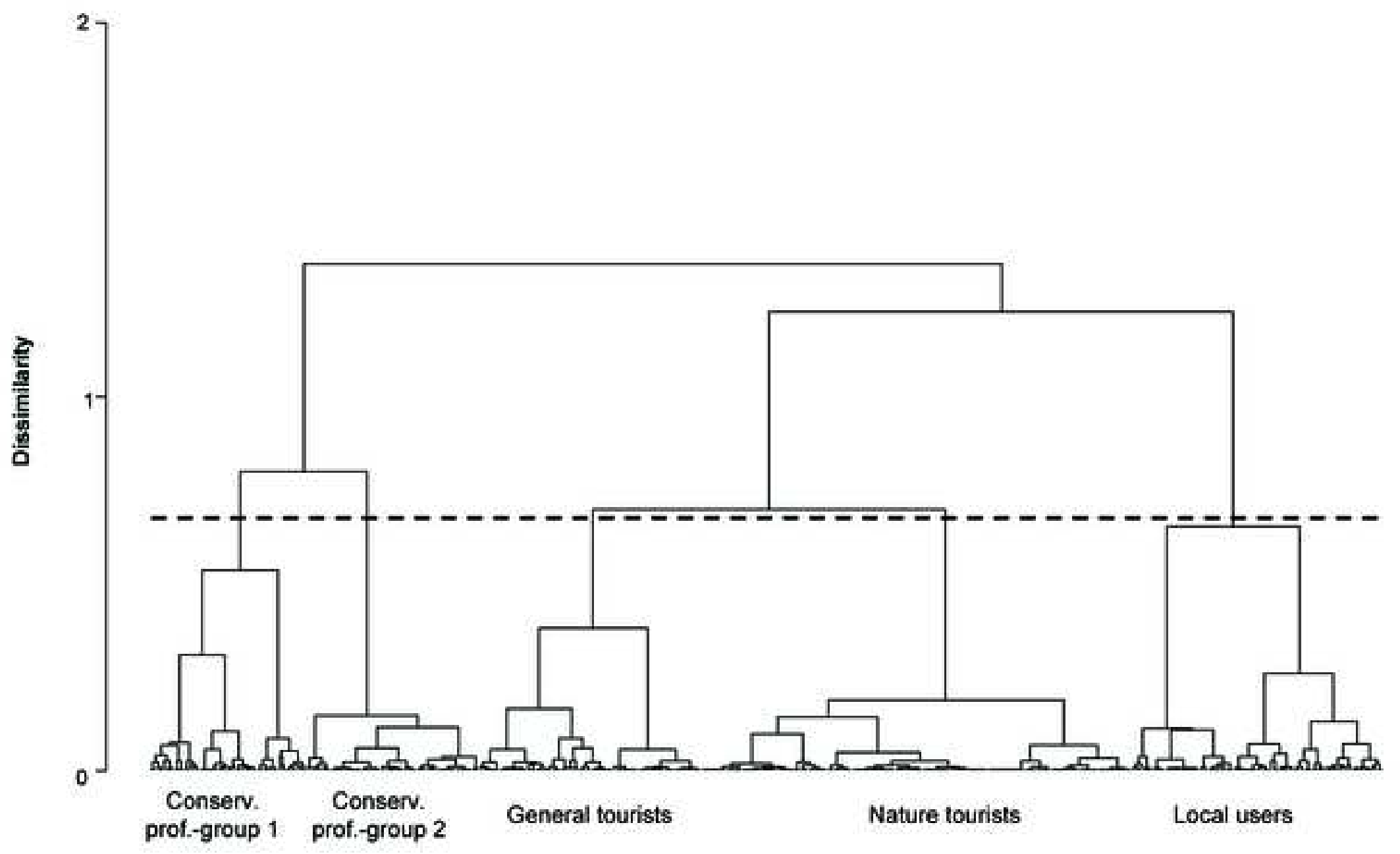




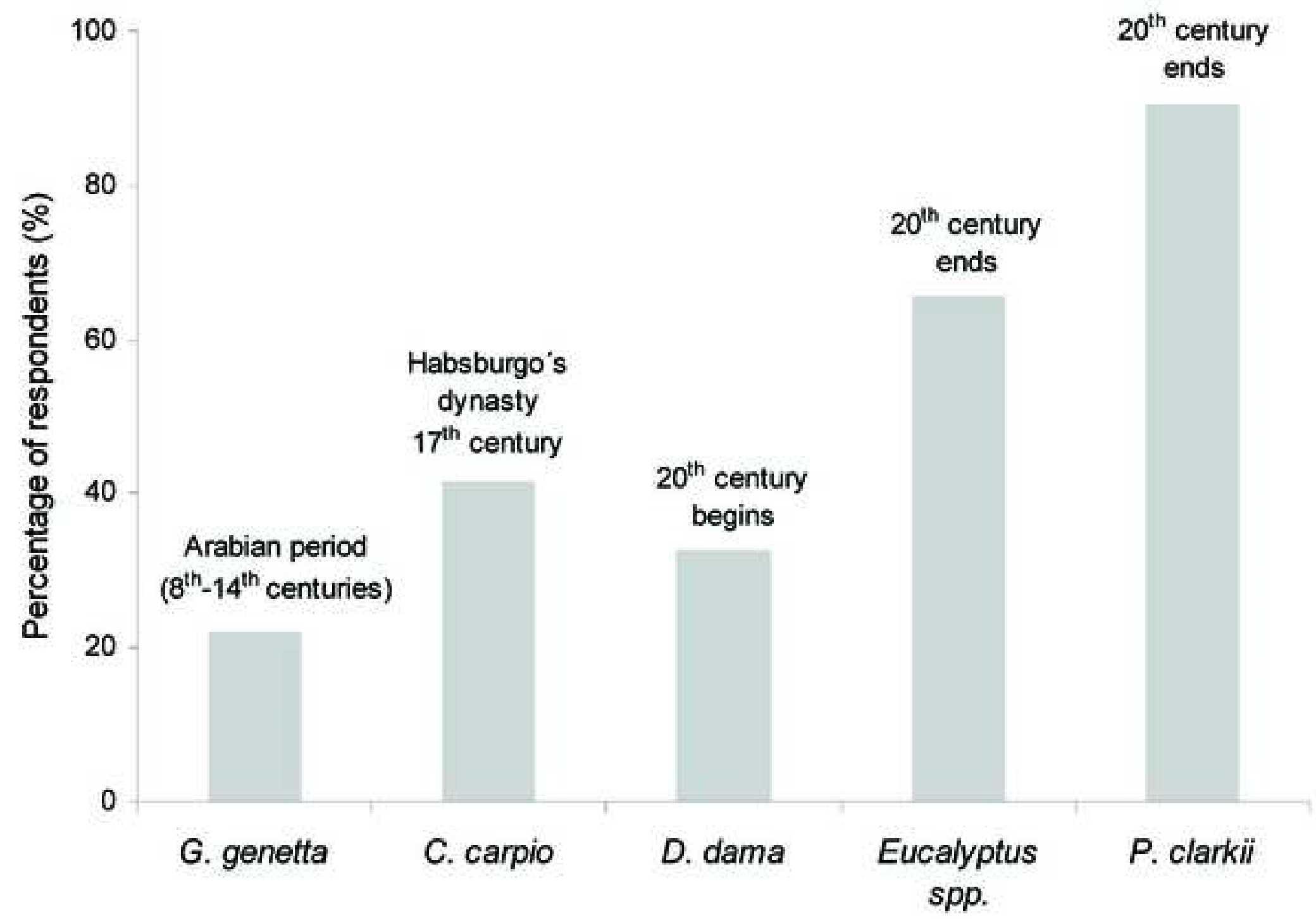




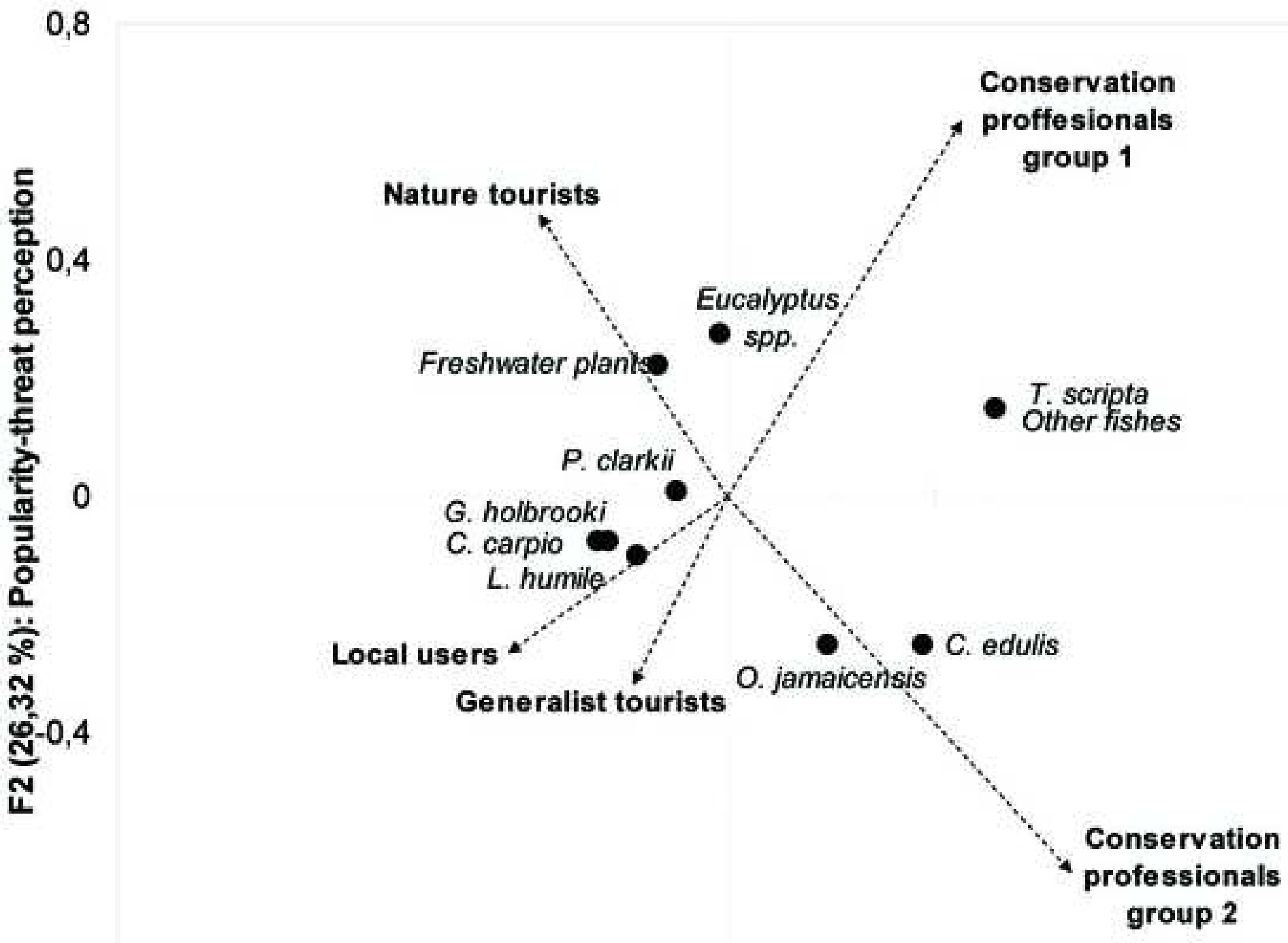

$-0,8$

$-0,8$

$-0,4$

0

0,4

0,8

F1 (58,59\%): Eradication vs research 